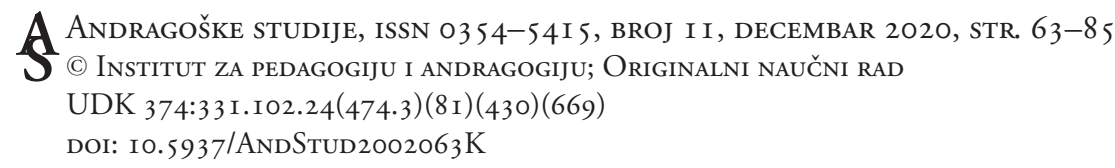

Jessica Kleinschmidt ${ }^{1}$, Jörg Schwarz ${ }^{2}$

Helmut Schmidt University, Germany

Kadine Lucas ${ }^{3}$

University of Lisbon, Portugal

Reinis Upenieks ${ }^{4}$

Riga Stradins University, Latvia

Adeniyi Adaramola ${ }^{5}$

Obafemi Awolowo University, Nigeria

\title{
Professionalisation Through Further Education? An International Comparison of Non-formal Education Programmes for Adult Educators
}

\begin{abstract}
Professionalism is a core topic in international discourse on adult education. Its importance is due not least to the need for professional self-assurance given the heterogeneity of the field of adult education, which is characterised not only by a wide range of working conditions, employment forms and responsibilities but also by the different qualifications and professional backgrounds of adult educators. Therefore, further education programmes for adult educators could be one important pillar in the professionalisation of adult education. At the same time, however, heterogeneous personnel structures make the seemingly simple question of further education for adult educators increasingly complex. While at the international level there is particular emphasis on professionalisation by means of academic degree programmes, the focus of the present paper is on

\footnotetext{
${ }^{1}$ Jessica Kleinschmidt is Doctoral Researcher at the Helmut Schmidt University, Germany (jessica.kleinschmidt@hsu-hh.de).

2 Jörg Schwarz, PhD is Postdoctoral Researcher at the Helmut Schmidt University, Germany (joerg.schwarz@ hsu-hh.de).

${ }^{3}$ Kadine Lucas is Doctoral Researcher at the University of Lisbon, Portugal (kadine@campus.ul.pt).

${ }^{4}$ Reinis Upenieksi is Doctoral Researcher at the Riga Stradins University, Latvia (reinis.upenieks@lu.lv).

${ }^{5}$ Adeniyi Adaramola is Doctoral Researcher at Obafemi Awolowo University in Ile Ife, Nigeria (adeniyiadaramola@gmail.com).
} 
non-formal further education for adult educators. It compares similarities and differences using country-specific examples of non-formal further education programmes for adult educators and seeks to explain them. The results are obtained using an international comparative research methodology. The cases (non-formal programmes) from Latvia, Brazil, Germany and Nigeria are examined by focusing on their target groups, structures, content and aims. The degree to which they are embedded in specific organisational and institutional structures and (national) policies also plays a role. The starting point for a critical reflection is the question: How can non-formal further education programmes contribute to the individual professionalisation of adult educators?

Key words: professionalisation, non-formal programmes, further education, adult educators, international comparison.

\section{Introduction}

The education of professionals plays a vital role in professionalisation. Since professionalisation has always been closely connected to academisation, debates on the professionalisation of adult education have also focused on the initial academic education of adult educators. In fact, today we can find many study programmes on adult education or at least general study programmes in educational sciences with a specialisation in adult education. At the same time, however, adult education is still a relatively open field in which people with very different disciplinary and professional backgrounds are active. Therefore, the systematic continuing education of professionals in adult education is of utmost importance. Since this form of professionalisation of adult educators has not been the focus of professionalisation research for a long time, the importance of continuing professional education and development (CPED) for professionalisation has been increasingly highlighted both by professional practice and academic research over the past decades.

In this article, we would like to focus precisely on this path of professionalisation of adult educators and examine forms of non-formal further education in an international comparative study. Using selected examples of good practice from Latvia, Brazil, Germany and Nigeria, we will examine the forms in which such offers of professionalisation could be institutionalised. In each case, we will identify the aims, target groups and key content of these programmes and, by means of a transnational comparison, determine their role in the respective country-specific system of adult education.

To this end, we will first examine the extent to which such further training programmes can be understood as professionalisation phenomena and classified in terms of professional theory, and we will develop comparative categories. The methodological procedure of the present transnational comparative study is de- 
scribed in the third section, which presents the basics of transnational comparative research and describes the specific data and analytical approaches used. In the fourth section, the four programmes under investigation are juxtaposed and compared according to the previously developed criteria of comparison. This allows for differences and similarities to be identified and, more importantly, interpreted in the fifth section. Finally, we will summarise the key results of the study, draw a conclusion and derive further research needs.

\section{Theoretical Background}

According to the traditional definition of a profession, one of the less controversial characteristics of a profession is its extensive scientific knowledge base. Professional practice relies on 'a body of knowledge and skill which is officially recognised as one based on abstract concepts and theories and requiring the exercise of considerable discretion' (Freidson, 2001, p. 180). Strong ties between universities and the professions have developed throughout their common history since the Middle Ages (Stichweh, 1994), which not only enable the mutual exchange and joint production of knowledge but also the regulation of the training of students, both in terms of content and access. As the production, application and transfer of knowledge go hand in hand, in traditional professions even the same person might occupy leading positions in both the professional and academic field (e.g. a chief medical officer at a hospital who also holds a professorship at a medical faculty).

Professionalisation, in the sense of achieving social recognition for a given profession, has usually focused on the academisation of vocational knowledge and training. In the case of adult education, while its roots as a field of study go back much further, an increasing number of degree programmes at universities developed in many Western countries especially in the middle of the $20^{\text {th }}$ century (Rubenson, 2010; Seitter, 2007). Subsequently, research on the professionalisation of adult education also focused initially on academisation and particularly the academic education of adult educators. But it can be argued that there are major processes of social change occurring in society in general and in academia, the occupational system and adult education in particular (Schwarz, 2016) that make such a limitation unproductive. It is thus important not to limit the examination of the knowledge base of professional practice to clearly delineated and disciplinarily justified bodies of knowledge that are imparted to students within the framework of a comprehensive course of study and instead to focus in particular on professionalisation through continuing professional education and development (CPED). 
This is particularly important if we assume that adult education cannot be understood as a profession in the classical sense. For example, there has never been a monopolisation of professional activity in adult education. Rather, this professional field is characterised precisely by the diversity of those working in it. The difference in professional expertise, especially of the teaching staff, is also an essential basis for the quality of adult education programmes. This makes it all the more important to examine the question of the educational foundations on which professional practice is undertaken. Such a shift in focus from the body of knowledge of an adult education profession as a social entity to a base of knowledge and skills underlying professional conduct can be theoretically embedded within the perspective of a 'new professionalism' (Egetenmeyer, Breitschwerdt, \& Lechner, 2019; Evetts, 2011). This approach not only acknowledges the complex structures, interdisciplinarity and multi-sourced base of knowledge but also emphasises the important role of organisations in the regulation of professional practice. Especially in the context of managerial transformation, organisations - that is, the adult education providers - have developed their own mechanisms that shape professional conduct. Quality, for example, is no longer perceived (only) as an issue of professionalisation but is addressed by systems of quality management and connected to strategic personnel management and development. On this basis, adult education providers as organisations play a significant role in defining the aims and measures of CPED for its professionals.

In addition to the academic paths of professionalisation, there are also a number of non-academic paths. This includes participation in informal education for adult educators. They don't follow a uniform professionalisation strategy but form a complex field of possibilities for individual professional development, possibilities that are very heterogeneous and, in their various forms, rarely related to one another, meaning we cannot speak of a uniform professionalisation strategy for adult educators. Non-formal education opportunities have a special place in this discussion and range from biographical and mainly informal learning opportunities to organised forms of further education. In the paper at hand, we will focus our examination on the latter by examining forms of non-academic professionalisation through further education, which we can systematically classify as non-formal education. According to Eurostat, these include 'any organised and sustained learning activities outside the formal education system', for example non-formal programmes, courses and guided on-the-job training (Eurostat, 2016). There are various certification models and procedures for acquiring new knowledge and certifying existing skills (Müller-Naevecke, 2019, p. 69). Aspiring adult educators can take part in educational programmes as early as during their studies or doctoral studies. The Adult Education Academy in Würzburg is 
a prime example of a programme that is based on a worldwide network of adult education students with practitioners from the field (Julius-Maximilian University Würzburg, 2020). A programme that targets adult educators at the beginning of their professional career is the 'Younger staff training' offered by the European Association for the Education of Adults, which operates on the European level (European Association for the Education of Adults, 2020). In the sense of lifelong learning, the aim would be to establish continuous further training along the entire career path of the adult educator.

This raises the question of which concept of professionalisation is realised by non-formal further education programmes for adult educators and how this is connected to the institutional context in which they are embedded. We will address this research question based on a comparative research approach by examining examples of such CPED programmes in four national contexts. In describing aims, target groups and content of the programmes, we can highlight commonalities and differences and relate them to different concepts of professionalisation. For a comparative analysis, it is vital to consider these programmes in their institutional contexts, which include country-specific structures of adult education on the one hand and specific organisational embeddedness on the other. In the next section, we will describe how our research methodology departs from these comparative categories.

\section{Methodology}

The theoretical perspectives on the professionalisation of adult educators developed above of course have consequences for its empirical examination. When we conceive of professionalism and of the structures and practices of professionalisation in adult education as social phenomena that developed over a long period of time, it becomes apparent that - just like other socio-historically developed structures - they tend to be perceived as 'normal' or even 'natural' (cf. Bourdieu, 1977). There is no better way than a transnational comparative research approach to remind us of the fact that everything could be completely different - and that it actually is different in other places in the world (Reischmann, 2008).

Our comparative research on professionalisation through further education started in the 2020 INTALL Würzburg Winter School (Egetenmeyer, 2017), where we undertook comparative group work on professionalisation through further education in a larger group of students and researchers. While we had the chance to clarify some of our theoretical concepts and categories for comparison, we had to focus the further analysis on selected cases from Latvia, Brazil, Germany and Nigeria. These four cases were chosen following a sampling strategy 
that strives for the simultaneous maximimisation or minimisation of both the differences and the similarities of data that bear on the categories being studied' (Glaser \& Strauss, 1967, p. 55). We selected cases from two European and two non-European countries, with the European countries Latvia and Germany having a very different history and being rooted in the 'Western' and 'Eastern' European tradition, respectively. Although Brazil and Nigeria share a postcolonial identity, they differ not only in their cultural traditions but also in their current socio-economic structures. All four countries occupy different ranks in the $\mathrm{Hu}-$ man Development Index (http://hdr.undp.org/en/2019-report). A contrastive comparison was also relevant in choosing the programmes analysed.

The data basis used was mainly found in scientific publications, policy papers and empirical reports. In addition, some data on the country context, especially information on the programmes examined, was crucial. For this purpose, in most cases we used online documents and websites. Additionally, it was highly relevant to compare authors from each country, not only because they were able to contribute their knowledge of and experience with the respective national system of adult education, but also because some of the data used was only available in the countries' native language. Below, we will first describe the aims, target groups, structure and content of each programme as well as its country-specific context. Only after juxtapositioning all of the cases can we discuss commonalities and differences and interpret the findings.

\section{First-aid Instructor Education in Latvia}

\section{Country-specific context}

As can be seen in the 2018 overview provided by the European Association for the Education of Adults, the promotion of adult education in Latvia remains a challenge due to relatively little public awareness of learning opportunities. In previous years, the Latvian government aimed to implement a national adult education governance structure to meet European and international targets and goals such as the Sustainable Development Goals. As part of the plan for the implementation of adult education governance, two recruitment stages of adult education course providers and learners were carried out. Courses and training programmes proposed by employers and other stakeholders underwent an approval process through the adult education governance committee. Furthermore, the Latvian Ministry of Education is working on implementing the EU's Upskilling Pathways Strategy (EAEA, 2018). 
The widely cited Belém framework for action (UIL, 2010) makes it clear: 'Quality in learning and education is a holistic, multidimensional concept and practice and demands constant attention and continuous development.' (UIL, 2010, p. 8) It requires 'relevant content and modes of delivery, learner-centred needs assessment, the acquisition of multiple competences and knowledge, the professionalisation of educators, the enrichment of learning environments and the empowerment of individuals and communities' (UIL, 2010, pp. 8-9). However, within Latvian policy and legislation, there is no reference to the professionalisation of adult educators. Although there is a general statement aiming at the quality of adult education in national documents, it lacks a focus on adult educators.

In terms of national-level developments regarding the quality of adult education, the UNESCO Institute for Lifelong Learning publication - known as GRALE 4 - should be consulted (UIL, 2019). This also refers to statements in previous publications: 'GRALE 2 furthered thinking about quality by looking at four features of ALE provision: (...) Training, employment conditions and professionalisation: Member States acknowledged the importance of training and continuing professional development of ALE teachers. (...) GRALE 3 reiterated and built on this understanding by closely tracking: Inputs to improving teaching methodologies. - Pre-service education and training programmes for ALE teachers. - Requirement of initial qualifications for teaching in ALE programmes. - Continuing in-service education and training for ALE teachers. - Inputs to improving teacher training, employment conditions, professionalisation. - Preservice education and training programmes for ALE teachers. - Requirement of initial qualifications for teaching in ALE programmes. - Continuing in-service education and training for ALE teachers.' (UIL, 2019, p. 62)

Although there is a national high-level policy paper on adult education, this rarely results in national-level public funding for adult education. There is also the European Social Fund for adult education (mainly $80 \%$ ESF funding and $20 \%$ self-funding), though this requires evidence of economic necessity; hard-skills education receives much more support than soft-skills education. Non-formal adult education programmes are very heterogeneous with a great diversity of topics. Programmes are mainly provided by for-profit companies. The political focus is on economics rather than learner needs.

An important national-level context must be taken into account. There are no legal requirements regarding certification or special qualifications for becoming an adult educator in a non-formal education setting in Latvia. Only teachers working in formal education settings such as preschool, primary and secondary education or lower-level vocational education are required to hold a degree in 
educational science. As there are few cases of adult learners entering secondary or lower-level vocational institutions, teachers are generally only prepared to teach children, teenagers and youngsters, but not adults. The teaching qualifications of a university teacher are evaluated by the faculty or by a board of professors. Even education law states: 'A person who has a pedagogical education or who is acquiring a pedagogical education which complies with the professional qualification requirements set by the government has the right to work as a teacher. These requirements shall not apply to non-formal adult education.' (Article 48, Education Law of Latvia, emphasis added)

\section{Case description}

Due to the lack of an overall framework of legal requirements for adult educators, there are specific requirements for those wishing to teach first aid. There is only one government institution, the State Emergency Medical Services, which is delegated to teach and to certificate first aid educators.

There are some prerequisites to participate in the programme: you have to be at least 18 years old and have at least a secondary education. The programme for educators lasts 68 hours (theoretical (T) 32 hours, practical (P) 36 hours), and the first 10 topics in the programme focus on education:

- Learning and memory: main learning theories; memory explained - 2 hours $\mathrm{T}$

- Information processing and learning motivation -2 hours $\mathrm{T}$

- Teacher 'factor' in the learning process. Student 'factor' in learning process -2 hours $\mathrm{T}$

- Choosing teaching materials. Planning teaching -1 hour T, 2 hours $\mathrm{P}$

- Different teaching / learning forms - 1 hour T, 2 hours P

- Conversation as a tool -1 hour T, 2 hours P

- Skills training. Involving students in skills training -1 hour T, 2 hours $P$

- Effectiveness of teaching and learning -1 hour T, 2 hours $P$

- Presentation techniques and tools. Learning environment - 1 hour T, 1 hour P

- Rhetoric, speech, non-verbal communication - 2 hours T

Thus, 25 out of 68 hours are devoted to education rather than the specifics of first aid. After the course, a candidate should acquire practical experience under the supervision of a certified first-aid teacher for 90 hours. Only then will the candidate be eligible for examination. The examination is 8 hours, including 
a knowledge test and skills demonstration (first aid and pedagogy). Only those who have passed the exam are certified. Recertification is necessary every five years. In order to be recertified, first-aid teachers should prove that they have conducted a certain amount of first-aid training and provide evidence of their professional development as a first-aid teacher (a minimum of 8 hours a year).

Adult education in Latvia is not based on any legal requirements to obtain certification or a special qualification to become an adult educator in a nonformal education setting. One of the courses examined as part of this study is a special programme for first-aid educators, which includes 25 hours dedicated to teaching. However, this is rather the exception than general practice. Although there are some references to the quality of adult education in policy documents, the authors of the present paper are not aware of any efforts to implement solutions regarding the quality of adult educators, their skills or performance.

\section{Adult Educator Education at Work in Brazil}

\section{Country-specific context}

To begin with, it is necessary to highlight that in Brazil the concept of adult education refers entirely to the provision of schooling for young people and adults who did not have the opportunity to finish schooling at the usual age. Adult education focuses on literacy and education for inclusion, aiming to compensate for the individual's lack of schooling. Although there have been a number of major literacy programmes since the 1940s, adult education was only officially recognised as a specific educational field in 1996 in the 'Guidelines and Bases for National Education (LDB)'. Following this, a 'National Curricular Guideline for Youth and Adult Education' was signed in 2000. Between 2003 and 2016, a national policy on adult education was pursued by the 'Secretariat for Continuing Education, Literacy, Diversity and Inclusion (SECADI)', which was closed in 2019. This secretariat established many programmes, such as 'Brazil Literate', 'Proeja' (vocational training), 'National Programme on Text Books for Adult Education' and others.

In general, there are two major areas of professionalisation activity in adult education: working as a teacher in regular adult education (sometimes connected with vocational training) and working as a literacy educator in non-formal programmes. In the first case, a bachelor's degree in pedagogy or a specific teaching subject is required. However, there is no bachelor's degree in adult education, so most of these teachers are not aware of specific adult education issues. Thus, 
non-formal further training is the most common way to achieve professionalisation. It is important to mention that, despite the requirement, 15 per cent of these adult educators do not have a college degree (Inep, 2019). This rate is the result of socioeconomic factors, inequality or poverty.

With regard to literacy programmes, no degree is usually required to be an adult educator - practical experience is considered more important. Nevertheless, because such programmes are not centralised but are instead provided by different organisations in different ways, sometimes informally, there is no national data on the degrees held by literacy educators. However, some information on the local context can be found. Santos and Oliveira (2017) analysed the profile of the 384 educators within the 'Brazil literacy' programme developed in the state of Bahia. They found that most of them $(61 \%)$ have only a secondary education, 4 per cent have a lower education, 30 per cent have a bachelor's degree and 3 per cent have specialised in other subjects. As no degree is required to work as a literacy educator, the programme focuses primarily on the initial and non-formal further education of the educators.

In this respect, the debates centre on both the formal higher education of adult educators and the non-formal qualification programmes for those who already work in adult education. Thus, the professionalisation of adult educators in Brazil is understood as two paths leading in the same direction: one way is to obtain a bachelor's degree while the other is through adequate working conditions (i.e. better remuneration), which allow educators to dedicate themselves fully to their job. Indeed, both are related, since a qualification provides access to better working conditions.

\section{Case description}

We will also focus on a case of adult educators' non-formal further education at work conducted by the Integrated Centre for Youth and Adult Education (Cieja). It was created between 2001 and 2004 in São Paulo city. This is a regular state school for young people and adults, offering literacy, basic and secondary education and with a focus on vocational training. It is provided to those who have not finished their schooling at the usual age. In this way, seeking an alternative to fast-paced education, Cieja proposes a new organisation of time, space and curriculum to take account of the needs of adult learners and to put into practice the idea of a popular education.

We examine a pluralistic timetable in which classes are distributed throughout the day in order to meet the students' requirements. In addition, teachers also 
have a 'special work week', with their timetable divided between teaching, preparing classes and joining collective further education sessions. This is the crucial point of Ciejas professionalisation proposal, since the teachers receive their salary not only to teach but also to take part in non-formal further education. Accordingly, it allows adult educators to undertake enough further education teaching to gain points for career advancement. Because of this, Cieja's philosophy is seen as a model for both an adult education curriculum and the professionalisation of adult educators.

There are 14 Cieja centres in São Paulo city, reaching 11,269 students. Each one has autonomy, a general coordinator as well as a specific pedagogical project. In this article, we focus on the centre located in the Campo Limpo neighbourhood, one of the most violent and socially vulnerable neighbourhoods in the city. Cieja Campo Limpo currently serves 1,600 students from the age of 15. We chose to analyse this centre because of its social and pedagogical role, involving the most active methodology, dialogue with the local community and the achievement of a systematic process of further education for adult educators.

Every adult educator within Cieja's structure must have a bachelor's degree and take part in the collective education session held every Friday for four hours - the 2018 report mentions 128 face-to-face further education hours during the year. The themes addressed are defined collectively in previous meetings between adult educators and the general coordinator, where they evaluate the previous year and discuss the demands of adult educators, national guidelines, the local community and students.

Although there are no guidelines for content, there are thematic frameworks governing the training process, for example the theoretical background of Cieja Campo Limpo, teaching students to read and write, the challenges of being young and poor, inclusion, the indigenous issue, maths education, pedagogical practice and the evaluation of adults within the schooling process.

This form of further education for adult educators is overseen either by the general coordinator or by invited experts and is based on the following methodological procedures: taking into account the everyday school environment; analysis of students' pedagogical tasks based on theoretical references; debates based on the meaningful experiences of educators.

The amount of time dedicated to each theme depends on the requirements of the adult educators as well as on specific class situations. As it is a large and heterogeneous team of adult educators, the group seeks to achieve a consensus regarding themes and time devoted to each subject. However, the decision of the majority prevails if a consensus is not achieved. 
In addition to career advancement, non-formal further education of adult educators at Cieja intends to adjust teaching to suit the local context. The further education proposal is based on the concept of popular education and was inspired by the critical pedagogy of Paulo Freire. Thus, discussing professionalisation from the perspective of the Integrated Centre for Youth and Adult Education presupposes explicit commitment not only to pedagogical and professional aspects but also to meaningful changes in students' social contexts.

\section{Basic Qualification in Adult Education in Germany}

\section{Country-specific context}

If we look at the different paths leading to the professionalisation of adult education in Germany, we can see that professionalisation takes place in both academic and non-academic contexts. Wb-personalmonitor, which describes the situation of personnel based on quantitative surveys, makes it possible to examine these two approaches. Wb-personalmonitor is the result of a research project funded by the German Ministry of Education and Research, which was conducted in cooperation with the German Institute for Adult Education from 2 January 2013 to 31 October 2015.

Academic professionalisation refers to the completion of university studies. A total of 57.7 per cent of adult educators have a university degree or a degree from a university of applied sciences (Koscheck \& Ohly, 2016, p. 110). It is important to note that these degrees are in a variety of subjects. Access to adult education jobs is possible with a degree in education or in a field not related to education. Among teachers in adult education, a degree in economics $(13.2 \%)$ is the most common (Koscheck \& Ohly, 2016, p. 119). A total of 33.4 per cent of adult educators have non-academic qualifications, that is, they have completed an apprenticeship or hold a master craftsman's diploma (Koscheck \& Ohly, 2016, p. 110). Germany lacks uniform professionalisation strategies in this respect.

Discussions about the professionalisation of adult educators in Germany focus not only on academisation, but also on further education. Measures in this context are very heterogeneous. They bear little relation to one another and are rarely tailored to adult education. According to wb-personalmonitor, 77.7 per cent of adult educators surveyed had participated in professional or general further education in the past twelve months. The average time spent in such measures was 56 hours per year (Koscheck \& Ohly, 2016, pp. 125ff). In her dissertation, Müller-Naevecke examined the participation of adult educators in 
organised further education for the purpose of updating their knowledge. The dissertation made no distinction between formal and non-formal further education formats. Since they began teaching, 19.9 per cent of teachers had taken part in this type of organised further education on educational subjects several times a year, while 34.3 per cent had taken part on average once a year. Organised further education on subjects relating to a specific field - that is, to the content of teaching - was considered more important. A total of 66.7 per cent participated one or more times a year or on average once a year (Müller-Naevecke, 2019, p. 199).

\section{Case description}

A non-formal further education programme entitled 'Basic Qualification in Adult Education' offered by the adult education association of Baden-Württemberg (Volkshochschulverband Baden-Würtemberg) was selected to illustrate the situation in Germany. The German institution of the Volkshochschule (VHS) is explained below.

With 894 adult education centres (2018), the VHS is Germany's largest provider of further education to the general public. In 2018, a total of 637,701 courses were offered, covering a large variety of fields. Courses in health and languages were particularly popular (Lux, Reichart, \& Huntemann, 2020, pp. 3ff). As an institution of adult education in Germany, the VHS sees itself as a further education institution for the general public. It is based on the idea that people can learn and want to learn and that education is a prerequisite for personal development and participation in society. In line with this principle, Volkshochschule students do not require formal school-leaving certificates or membership. VHS adult education centres are open to all social classes, all age groups, all nations and all kinds of needs (Süssmuth \& Eisfeld, 2018, pp. 764ff). The German Adult Education Association (Deutscher Volkshochschul-Verband e. V. - DVV) is the umbrella organisation of all regional VHS associations in Germany. The DVV supports cooperation and the exchange of knowledge among its members, develops policies and guidelines and promotes the quality of adult education and international cooperation (Süssmuth \& Eisfeld, 2018, p. 781). The association has sixteen regional associations representing the German states. One of them is the adult education association of Baden-Württemberg, which has 169 adult education centres and more than 660 branch offices (Volkshochschul-Verband Baden-Württemberg, 2020).

The non-formal further education programme 'Basic Qualification in Adult Education' is tailored to the target group of VHS teachers of all subject 
areas employed at adult education centres. VHS statistics for 2018 show that this job is a secondary occupation for the majority of VHS staff, or they are freelancers. A total of 122,195 course teachers were female and 57,739 were male (Lux et al., 2020, p. 22). Teachers at adult education centres participate in further education programmes several times a year, which is more often than those from other further education providers (Müller-Naevecke, 2019, p. 203).

The further education programme 'Basic Qualification in Adult Education', developed by the German Adult Education Association, is a key tool for ensuring the quality of teaching at German adult education centres. This programme has been implemented by all regional associations, although there are differences in content and organisation. The programme for staff of adult education centres in Baden-Württemberg is described below. The following paragraph is based on data from the further education programme of this regional association for February to September 2020 (cf. Volkshochschul-Verband BadenWürttemberg, 2019).

The further education programme 'Basic Qualification in Adult Education' is designed to help teachers acquire, extend and enhance their skills in adult education, didactics, methodology and communication as well as their personal skills. Further aims are to promote the exchange between teachers and to encourage self-reflection. A total of 80 lessons must be completed in order to achieve these goals. Teachers are free to spread the courses over a period of three years, but their selection must cover different areas. A minimum of eight courses must be marked as 'BQAE' (Basic Qualification in Adult Education) in the directory. There is a large variety of topics and related courses. The adult education association of Baden-Württemberg, for example, offers the following courses in the field of 'Teaching and Learning': 'Moderation Techniques in Teaching' and 'How to Prepare, Design and Present Digital Course Contents'. The courses 'Voice Training' and 'A Good Story May Work Better Than a Long Speech' belong to the area of 'Communication'. The following courses focus on the teacher's personality: 'Time and Stress Management' and 'How to Act with Self-Confidence as a Seminar Teacher'. Furthermore, courses from the areas 'How to Lead Groups' and 'Course Management' can also be selected. In addition to basic qualification courses, a maximum of two courses may be chosen which belong to the subject taught. These depend on the individual wishes of the course teacher. Upon completion of the above-mentioned requirements and submission of the individual certificates of attendance, the adult education association of Baden-Württemberg will issue an overall certificate of 'Basic Qualification in Adult Education' (cf. Volkshochschul-Verband Baden-Württemberg, 2019). 


\section{A Train-the-Trainer Programme in Nigeria}

\section{Country-specific context}

In terms of professionalising adult educators in Nigeria, there is a strong emphasis on academisation. The universities offer different bachelor's and master's degrees with a focus on adult education. Finding non-formal training programmes for adult educators is more difficult. For the present comparison, the 'train-thetrainer programme' was selected. Initial research has already revealed a variety of political influences on the programme. Hence, it is important to begin by looking at the main political organisations and concepts related to adult education in Nigeria.

The general aims and content of adult education are clearly stated in the Nigerian National Policy on Education (NPE). The NPE (Federal Republic of Nigeria, 2013) regards adult education and non-formal education as basic education provided to adults and young people outside the formal school system. The goals of ALE/non-formal education in Nigeria are also laid down in the NPE (Federal Republic of Nigeria, 2013). They include the provision of basic education for adults and young people who have never had the advantage of formal education or who left school early, remedial and lifelong education for young people and adults who did not complete school, and further education for different categories of school leavers from the formal education system to improve their basic knowledge and skills. Other goals include offering in-service, vocational and professional training for different categories of workers and professionals to improve their skills and providing adults with an aesthetic, cultural and civic education for the purpose of raising public awareness (Federal Republic of Nigeria, 2013). Adult education in Nigeria is based more on non-formal education with the responsibility to re-educate and re-train adults to be competitive in the global economy and to be financially independent.

The National Commission for Mass Literacy and Adult and Non-formal Education (NMEC) is the umbrella organisation for developing and organising adult education and non-formal education programmes in the country. The NMEC has an office in each of the country's six zones, and these have control over 36 state agencies comprising 774 local government area adult education departments and non-formal education centres. The NPE tasks NMEC with coordinating mass literacy, adult and non-formal education programmes nationwide and training adult educators for the state agencies using appropriate strategies, as well as with organising national and international trainings, workshops, seminars, lectures and symposia on issues in adult and non-formal education. Thus, 
the NMEC is able to train adult education facilitators, coordinators, scheme organisers, library attendants and administrative officers with the help of academic professionals from the tertiary institutions. In this context, it should be pointed out that most practitioners in the field of adult education in Nigeria are non-professionals. Research by Junaid (2001, as cited in Alkali, 2016) suggests that 71 per cent of adult education staff are non-professionals. With regard to these political goals and the need to professionalise non-professionals in the field of adult education as well as improving the skills and knowledge of professionals, the NMEC Policy Guide (2017) states that the commission trains grassroots personnel such as facilitators, area coordinators, scheme organisers, library attendants and administrative officers of adult education through a 'train-the-trainer programme'. This programme focuses on non-certified adult educators who have knowledge, skills and experience in other subject areas. Often these people also have academic degrees in other scientific disciplines outside adult education. However, the minimum qualifications for adult educators in Nigeria is the National Certificate in Education (NCE), ideally in adult education and non-formal education courses.

\section{Case description}

The train-the-trainer programme is viewed as an introductory course. It offers individuals without an NCE certificate the opportunity to start a career as a professional adult educator.

The programme is a two-week induction course which runs twice a year for 336 hours. The course covers essential topics of adult education, such as programme development, psychology of adults, adult teaching methodologies, communication skills and research methods. In addition, general social issues are also addressed, for example climate change, civic education, human rights, health education and cultural diversity. The variety of topics indicates that there is a close connection between adult education and social problems. However, specialisation based on the individual wishes of the participant is not possible. The content is specified by the organisation and is firmly anchored in the programme.

Professional adult educators are familiarised with new ideas and innovations during seminars and workshops in the programme, after which participants are given a certificate of attendance. This certificate is recognised at national level. However, this alone is not considered a professional adult education qualification in Nigeria. This requires an academic degree or non-formal further training. The main aim of the programme is to equip adult educators with the knowledge and skills needed to become facilitators in order to install in the population the spirit 
of personal and national development. At this point, it becomes clear that this is a state programme. The personal development of the adult educator tends to be of secondary importance.

\section{Comparison and Interpretation}

Although the cases presented here might at first appear to differ in many ways, our aim is to compare them in order to provide different answers to the same social problem, namely, the most effective way to professionalise adult educators beyond tertiary education and formalised study programmes. What all of the programmes presented have in common is that they are primarily aimed at adult educators who are mainly focused on the facilitation of learning processes in direct interaction - in short: teaching.

In comparing the content, we can state that teaching skills play a vital role in all of the programmes and seem to represent a minimum requirement of what an adult educator has to know and be able to do. Nonetheless, this leaves much room for interpretation, and other aspects of programme content indicate different approaches. First, there are different disciplinary priorities. While in the case of Latvia, for example, we find psychological approaches (learning and memory, motivation ...), the Brazilian case utilises knowledge connected to sociology, politics and social work (youth and poverty, inclusion ...). This contrasts with the more individualistic approach in the Latvian case, which centres on the adult learner and a more social approach to the situation of learning and the relation between learners and the adult educator. The Nigerian case is located between the Latvian and the Brazilian approach. While psychological knowledge is explicitly relevant, it also emphasises the relevance of knowledge of the learning environments and broader social developments. The German case is difficult to categorise in terms of content, which may differ considerably depending on the course chosen by the learners. This may result in a well-rounded mix of content but also in the somewhat one-sided education of adult educators.

With regard to the aims of the programmes, we see an instrumental concept of educating adult educators competing with a more normative one. On the one hand, the pedagogical knowledge and skills imparted in the programmes are seen as a means of ensuring successful educational processes and a certain quality of adult education. On the other hand, there is the (classical) pedagogical claim of serving a higher purpose, such as contributing to societal transformation. The Latvian approach, but also the Nigerian one, tends to have a more instrumental aim, while in the case of Brazil, the emancipatory aim is explicitly emphasised. 
Again, in Germany, the freedom to choose courses makes the programme more dependent on the interests of the participants.

This is mirrored in the (time-related) composition of the courses. While the Latvian and Nigerian programmes are to be completed before starting work as an adult educator, the Brazilian programme can only be completed while already actively working in adult education, and in Germany it is usually the case that the programme is undertaken once teaching work has commenced. This also corresponds with the higher degree of formalisation of the programmes in Latvia and Nigeria and their organisation by national government institutions, whereas the Brazilian programme is carried out by a government institution in the context of a local municipality, whereas the German programme is linked to the regional association of adult education centres.

\section{Lessons Learned}

As stated earlier, we support the argument that a transnational comparative research approach can enhance our reflexivity substantially - thus, we eventually have to discuss achievements and shortcomings of our analysis. In our paper, we examined how the professionalisation of adult educators is being supported by further education programmes in four different national contexts, namely Brazil, Germany, Latvia and Nigeria. But although we approached the investigation with a clear idea of the programmes we wanted to compare, a much wider range of different offers for the further education of adult educators soon became apparent. On the one hand, this helped to reveal significant differences between the cases in our comparison; on the other hand, it also revealed the needs as well as the possibilities for a further differentiation of comparative categories in future investigations.

Regarding the differences we found, the comparative categories aims and contents proved insightful, and it can be argued that a specific relation between them stands out eventually. While we differentiated between a rather instrumental and a more emancipatory approach regarding the general aims of the programmes, the knowledge structures and disciplinary references of the contents focused more on teaching methods, the adult learner and psychology on the one hand and on societal problems, emancipatory education and sociology I politics on the other hand. We think that these configurations are an expression of overarching differences between different traditions and cultures of adult education thus being reproduced also by further education programmes for (future) adult educators. 
Regarding the needs and possibilities for the further development of the comparative categories used in our analysis, it has to be discussed if the cases chosen for comparison, though clearly being cases of non-formal education programmes for adult educators, still show too much internal heterogeneity to be suitable for a meaningful comparison: We have shown examples both of continuous on-the-job training with a tendency towards team supervision and traditional preparatory courses; our sample includes voluntary as well as compulsory offers; and the programs are organised on the level of the national government, of adult education associations or (governmental) adult education organisations. These differences led to a great richness in the comparison of our cases. But at the same time, the mentioned differences must be systematically used as comparative categories for future investigations. Thus, future international comparisons can be carried out on a more specific level and focus, for example, on the role of self-organised training in institution teams (as in our Brazilian case). Thus, the results elaborated here can hopefully inspire and guide future research on professionalisation through further education.

\section{References}

Alkali, M. (2016). Professionalism in adult education: The surest way for effective administration of adult education in Nigeria. International Journal of New Technology and Research, 2(9), 76-80.

Bourdieu, P. (1977). Outline of a theory of practice. Cambridge: Cambridge University Press.

European Association for the Education of Adults. (2018). Adult education in Europe 2018: A civil society view. Retrieved from https://eaea.org/wp-content/uploads/2018/11/Country_Reports_2018_final.pdf.

European Association for the Education of Adults. (2020). Trainings. Retrieved from https://eaea.org/our-work/capacity-building/eaea-trainings/.

Egetenmeyer, R., Breitschwerdt, L., \& Lechner, R. (2019). From 'traditional professions' to 'new professionalism': A multi-level perspective for analysing professionalisation in adult and continuing education. Journal of Adult and Continuing Education, 25(1), 7-24. https://doi.org/10.1177/1477971418814009

Egetenmeyer, R. (2017). The internationalisation of studies in adult education: The example of COMPALL: Comparative Studies in Adult Education and Lifelong Learning. Andragoška spoznanja, 23(4), 121-134. https://doi.org/10.4312/ as.23.4.121-134

Eurostat. (2016). Adult learning statistics: Characteristics of education and training. Luxemburg: Eurostat. Retrieved from https://ec.europa.eu/eurostat/statisticsexplained/index.php/Adult_learning_statistics___characteristics_of_education_ and_training. 
Evetts, J. (2011). A new professionalism? Challenges and opportunities. Current Sociology, 59(4), 406-422. https://doi.org/10.1177/0011392111402585

Federal Republic of Nigeria. (2013). Nigerian National Policy on Education (NPE). Lagos: NERDC.

Freidson, E. (2001). Professionalism: The third logic. Cambridge: Polity Press.

Glaser, B., \& Strauss, A. (1967). The discovery of grounded theory: Strategies for qualitative research. New Brunswick: Aldine.

INEP. (2019). INEP data 2017. Brasília: INEP. Retrieved from http://portal.inep.gov.br/ sinopses-estatisticas-da-educacao-basica Retrived 2019-11-27.

Julius Maximilians Universität Würzburg. (2020). Adult Education Academy. Retrieved from https://www.paedagogik.uni-wuerzburg.de/lifelonglearning/home/

Koscheck, S., \& Ohty, H. (2016). Qualifikation des Personals in der Erwachsenenund Weiterbildung. In A. Martin, S. Lencer, J. Schrader, S. Koscheck, H. Ohly, R. Dobischat, A. Elias, \& A. Rosendahl (Eds.), Das Personal in der Weiterbildung: Arbeits- und Beschäftigungsbedingungen, Qualifikationen, Einstellungen zu Arbeit und Beruf (pp. 107-131). Bielefeld: Bertelsmann.

Lux, T., Reichart, E., \& Huntemann, H. (2020). Volkshochschul-Statistik. Retrieved from https://www.die-bonn.de/doks/2019-volkshochschule-01.pdf.

Müller-Naevecke, C. (2019). Wie bildet sich die Weiterbildung? Studie zur Erschließung von Fachinformationen. Bielefeld: Bertelsmann.

National Commission for Mass Literacy, Adult and Non-Formal Education (NMEC). (2017). Policy guidelines for mass literacy, adult and non-formal education in Nigeria. Abuja: Yaliam Press.

Reischmann, J. (2008). Comparative adult education: Arguments, typology, difficulties. In J. Reischmann \& M. Bron (Eds.), Comparative adult education 2008. Experiences \& examples (pp.19-32). Frankfurt am Main: Peter Lang.

Rubenson, K. (2010). Adult education overview. In P. Peterson, E. Baker, \& B. McGaw (Eds.), International encyclopedia of education (pp. 1-11). Retrieved from https:// doi.org/10.1016/B978-0-08-044894-7.01723-1

Santos, A. \& Oliveira, J. (2017). O programa todos pela alfabetização: Perfil dos alfabetizadores. Paper presented at XII Colóquio Nacional e V Colóquio Internacional do Museu Pedagógico, Vitória da Conquista.

Schwarz, J. (2016). Umkämpfte Professionalität: Eine praxistheoretische Analyse zur Institutionalisierung pädagogischer Praxisformen im Feld der Gründungsberatung. Marburg: Philipps-Universität. https://doi.org/10.17192/z2016.0940

Seitter, W. (2007). Geschichte der Erwachsenenbildung. Eine Einführung. Bielefeld: Bertelsmann.

Stichwer, R. (1994). Wissenschaft, Universität, Professionen. Soziologische Analysen. Frankfurt am Main: Suhrkamp.

Süssmuth, R., \& Eisfeld, K. H. (2018). Volkshochschule. In R. Tippelt \& A. von Hippel (Eds.), Handbuch Erwachsenenbildung/Weiterbildung (pp. 763-784). Wiesbaden: Springer VS. 
UIL (UNESCO Institute for Lifelong Learning). (2010). Belém framework for action: Harnessing the power and potential of adult learning and education for a viable future. Hamburg: UIL. Retrieved from https://unesdoc.unesco.org/ark:/48223/pf 0000187789? posInSet=2\&queryId=4bdb196a-c2cf-4914-a7d0-b33cdc72425b

UIL (UNESCO Institute for Lifelong Learning). (2019). Leave no one behind: Participation, equity and inclusion. $4^{\text {th }}$ Global Report on Adult Learning and Education (GRALE 4). Hamburg: UNESCO Institute for Lifelong Learning. Retrieved from https://unesdoc.unesco.org/ark:/48223/pf0000372274

VOlKSHOCHSCHULVERBAND BADEN-WÜRTTEMBERG. (Ed.) (2019). vhs informationen fortbildung 2020. Informationen \& Fortbildungen. Ausgabe 2/2020. Retrieved from https://www.vhs-bw.de/fortbildung/vhs-info.pdf

Volkshochschulverband BAden-WürtTemberg (2020). Der Volkshochschulverband Baden-Württemberg. Retrieved from https://www.vhs-bw.de/wir-ueber-uns/vhsverband/der-vhs-verband.html 
Jessica Kleinschmidt ${ }^{6}$, Jörg Schwarz

Univerzitet Helmut Šmit, Nemačka

Kadine Lucas ${ }^{8}$

Univerzitet u Lisabonu, Portugalija

Reinis Upenieks 9

Univerzitet Riga Stradins, Letonija

Adeniyi Adaramola ${ }^{10}$

Univerzitet Obafemi Awolowo, Nigerija

\section{Profesionalizacija kroz dalje obrazovanje? Međunarodno poređenje neformalnih obrazovnih programa za nastavnike $u$ obrazovanju odraslih}

Apstrakt: Profesionalizam je ključna tema međunarodnog diskursa o obrazovanju odraslih. Ona je značajna ne samo zbog potrebe za profesionalnim samopouzdanjem s obzirom na heterogenost oblasti obrazovanja odraslih, koju karakterišu ne samo širok spektar uslova rada, oblici zaposlenja i odgovornosti već i različite kvalifikacije i profesionalna pozadina nastavnika u obrazovanju odraslih. Stoga bi programi daljeg obrazovanja mogli biti jedna od važnih komponenti u profesionalizaciji obrazovanja odraslih. Međutim, heterogene kadrovske strukture istovremeno čine naizgled jednostavno pitanje daljeg obrazovanja za nastavnike odraslih sve kompleksnijim. Dok na međunarodnom nivou postoji poseban naglasak na profesionalizaciji putem akademskih diplomskih programa, fokus ovog rada je na neformalnom daljem obrazovanju za nastavnike odraslih. U ovom radu se upoređuju sličnosti i razlike na primerima neformalnog daljeg obrazovanja za nastavnike odraslih u određenim zemljama i nastoji se da se one objasne. Rezultati su dobijeni primenom međunarodne metodologije uporednog istraživanja. Slučajevi (tj. neformalni

\footnotetext{
${ }^{6}$ Jessica Kleinschmidt je istraživač doktorand na Univerzitetu Helmut Šmit, Nemačka (jessica.kleinschmidt@ hsu-hh.de).

${ }^{7}$ Dr Jörg Schwarz je istraživač postdoktorand na Univerzitetu Helmut Šmit, Nemačka, (joerg.schwarz@hsuhh.de).

${ }^{8}$ Kadine Lucas je istraživač doktorand na Univerzitetu u Lisabonu, Portugalija (kadine@campus.ul.pt).

${ }^{9}$ Reinis Upenieks je istraživač doktorand na Univerzitetu Riga Stradins, Letonija (reinis.upenieks@lu.lv).

${ }^{10}$ Adeniyi Adaramola je istraživač doktorand na Univerzitetu Obafemi Awolowo, Ile Ife, Nigerija (adeniyiadaramola@gmail.com).
} 
programi) iz Letonije, Brazila, Nemačke i Nigerije ispituju se s fokusom na njihove ciljne grupe, strukture, sadržaj i ciljeve. Stepen do kojeg su uključeni u specifične organizacione i institucionalne strukture i (nacionalne) politike takođe je značajan. Polazna tačka za kritičku refleksiju je pitanje: kako programi neformalnog daljeg obrazovanja mogu doprineti individualnoj profesionalizaciji nastavnika za odrasle.

Ključne reči: profesionalizacija, neformalni programi, dalje obrazovanje, obrazovanje odraslih, nastavnici u obrazovanju odraslih, međunarodno poređenje. 